\title{
Replacement of native vegetation alters the soil microbial structure in the Pampa
}

\section{biome}

\author{
Afnan Khalil Ahmad Suleiman ${ }^{1}$, Victor Satler Pylro ${ }^{2 *}$, Luiz Fernando Wurdig Roesch ${ }^{3}$
}

${ }^{1}$ Federal University of Santa Maria - Dept. of Soils, Av. Roraima, 1000 - 97105-900 - Santa Maria, RS - Brazil. 2René Rachou Research Center - Genomics and Computational Biology, Av. Augusto de Lima, 1715 - 30190002 - Belo Horizonte, MG - Brazil.

${ }^{3}$ Federal University of Pampa - Campus São Gabriel, Av. Antonio Trilha, 1847 - 97300-000 - São Gabriel, RS Brazil.

*Corresponding author <victor.pylro@gmail.com>

Edited by: Fernando Dini Andreote

Received December 28, 2015

Accepted April 25, 2016

\begin{abstract}
Land use change is one of the the major factors related to soil degradation and alterations in soil microbial diversity and structure. In this study, we aimed to evaluate the microbial shifts caused by deforestation of a small area of a natural forest for the introduction of a pasture in the Brazilian Pampa. The microbial abundance and structure were evaluated by molecular approaches based on quantitative Polymerase Chain Reaction (qPCR) and Ribosomal Intergenic Spacer Analysis (RISA). The microbial communities did not present significant quantitative differences, but the environmental impact caused by deforestation changed the structure of the bacterial and archaeal communities. Taking into account the percentage of shared OTUs (operational taxonomic units) of each domain evaluated, we concluded that the domain Bacteria were more influenced by the deforestation than the Archaea. A total of $22 \%$ of bacterial OTUs and $50 \%$ of the archaeal OTUs were shared between forest and grassland leading us to conclude that the environment evaluated presented a core microbial community that did not suffer modification caused by land use change.

Keywords: RISA, soil quality, land use change, soil microbial ecology
\end{abstract}

\section{Introduction}

The Brazilian Pampa encompasses an area of $63 \%$ of the state of Rio Grande do Sul. Because of its natural grasslands, livestock production is one of the main economic activities (Roesch et al., 2009). Despite its ecological and economical importance, anthropogenic land use in the Pampa biome has changed the structure of natural plant and animal communities by the introduction of exotic species and conversion of natural areas into agricultural land. It is estimated that half of the original vegetation has been removed and transformed into other types of vegetation (Overbeck et al., 2006).

Deforestation and conversion of natural areas into agricultural land are the main drivers of global environmental warming associated with climate change, species extinction and loss of ecosystem functions (Tilman et al., 2001). Intensive agricultural practices are an important factor contributing to the degradation of soil properties (García-Orenes et al., 2009; Maitima et al., 2009), leading to lower levels of organic matter (Fliessbach et al., 2007; Schjønning et al., 2007) and alterations in soil microbial diversity and activity (Nicol et al., 2003; Govaerts et al., 2007). Many studies have shown that land use determines the composition of soil bacterial communities (Wallenius et al., 2011; Osborne et al., 2011) and the bacterial communities are more sensitive to land use changes than the soil chemical and physical properties (Romaniuk et al., 2011). On the other hand, the land use affected indirectly the bacterial community structure but it does not deplete bacterial diversity under the environmental conditions imposed (Jesus et al., 2009; Suleiman et al., 2013).

Knowledge of how microbial diversity is influenced by soil management systems may help us to under- stand the carbon balance, energy flow, and greenhouse gas fluxes in these areas that have shifted. Such knowledge is fundamental to the sustainable management of forest and agricultural ecosystems in this threatened biome. Little is currently known about the diversity, abundance, and structure of soil microbial communities in the Pampa biome. Most of the microbial studies in the Pampas have been focused on the bacterial diversity for want of archaeal diversity information (Suleiman et al., 2013; Lupatini et al., 2013a, b). Describing how bacterial and archaeal communities are altered during ecosystem development can thus provide fundamental insights into above and belowground linkages and ultimately explain whether these feedbacks underlie patterns of microbial communities in the Brazilian Pampa. In this study we tested the hypothesis that the conversion of forest cover by pasture will cause shifts in soil archaeal and bacterial communities. However, these domains will react in different ways, one being more affected than the other.

\section{Materials and Methods}

Site description, soil sample, physicochemical analysis and DNA extraction

The samples were collected from within the Pampa biome in a soil classified as Paleudult (U.S. Soil Taxonomy) under a native forest and under a pasture in the Vila Nova do Sul municipality (the sampling coordinates are presented in Table 1). The physicochemical properties of soil location, altitude, temperature and precipitation of the study sites are shown in Table 1. The sampling areas were under the same edaphoclimatic conditions and had the same soil textural class with similar sand and clay content. Grassland resulted from the deforestation of a small area $\left(5,500 \mathrm{~m}^{2}\right)$ inside 
Table 1 - Location, altitude, temperature, precipitation and soil chemical characteristics of soils under native forest and pasture.

\begin{tabular}{|c|c|c|}
\hline Coordinates & Forest & Pasture \\
\hline & $\begin{array}{l}30^{\circ} 24^{\prime} 09.3^{\prime \prime} \mathrm{S} \\
53^{\circ} 52^{\prime} 59.1^{\prime \prime} \mathrm{W}\end{array}$ & $\begin{array}{l}30^{\circ} 24^{\prime} 08.9^{\prime \prime} \mathrm{S} \\
50^{\circ} 53^{\prime} 05.9^{\prime \prime} \mathrm{W}\end{array}$ \\
\hline Altitude & 616 & 616 \\
\hline Accumulated total precipitation $(\mathrm{mm})^{\mathrm{a}}$ & 100 & 100 \\
\hline Average low temperature $\left({ }^{\circ} \mathrm{C}\right)^{\text {a }}$ & 10.2 & 10.2 \\
\hline Average high temperature $\left({ }^{\circ} \mathrm{C}\right)^{\mathrm{a}}$ & 19.5 & 19.5 \\
\hline $\mathrm{pH}$ & $5.8( \pm 0.2)$ & $5.65( \pm 0.1)$ \\
\hline $\mathrm{Ca}+\mathrm{Mg}\left(\mathrm{cmol}_{\mathrm{c}} \mathrm{kg}^{-1}\right)$ & 39.0 & 23.2 \\
\hline $\mathrm{Al}\left(\mathrm{cmol}_{\mathrm{c}} \mathrm{kg}^{-1}\right)$ & 0.5 & 0.1 \\
\hline $\mathrm{Na}\left(\mathrm{cmol}_{\mathrm{c}} \mathrm{kg}^{-1}\right)$ & 0.01 & 0.01 \\
\hline $\mathrm{K}\left(\mathrm{cmol}_{\mathrm{c}} \mathrm{kg}^{-1}\right)$ & 0.6 & 1.0 \\
\hline$P(m g ~ k g-1)$ & 39.0 & 12.0 \\
\hline Total organic carbon $\left(\mathrm{g} \mathrm{kg}^{-1}\right)$ & 73 & 32.9 \\
\hline Humina ( $\mathrm{g} \mathrm{kg}^{-1}$ ) & 60.3 & 24.4 \\
\hline Humic acid $\left(\mathrm{g} \mathrm{kg}^{-1}\right)$ & 7.3 & 5.5 \\
\hline Fulvic acid $\left(\mathrm{g} \mathrm{kg}^{-1}\right)$ & 5.0 & 4.1 \\
\hline
\end{tabular}

aData from June 2010.

the forest for a non-commercial cattle settlement. Pastures were not fertilized, except for the entry of manure added to the soil by animal activity. Furthermore, no correction was made to the soil $\mathrm{pH}$ and exotic plants were not introduced into this area. The native forest showed a greater number of plant families in comparison to pasture. The most common native trees that were found in the forest belong to the following families: Boraginaceae, Euphorbiaceae, Fabaceae, Lauraceae, Malvaceae, Meliaceae, Myrtaceae, and Rutaceae. In the pasture, the most dominant grass species belong to the Poaceae family.

For microbial community analysis, soil samples were collected following the experimental design proposed by Baker et al. (2009) for each land use. The samples were taken by drawing four randomly distributed $1 \mathrm{~m}^{2}$ plots per land use. The soil was collected with a sterile core to a depth of $0-10 \mathrm{~cm}$ and $5 \mathrm{~cm}$ in diameter during the spring of 2010. Sub-samples were taken from every corner of the square, pooled and mixed to form four composite samples from the native forest and four composite samples from the pasture. Soil samples were stored in sterile bottles in ice, until transportation to the laboratory on the same day and were stored at $-20{ }^{\circ} \mathrm{C}$ until DNA extraction and soil chemical analysis. At the time of DNA extraction, plant roots and other particles found in the soil were removed. Soil chemical analysis of $\mathrm{pH}$, concentrations of $\mathrm{Ca}+\mathrm{Mg}, \mathrm{Al}, \mathrm{K}, \mathrm{Na}, \mathrm{P}$ and total organic carbon (TOC) were performed according to Embrapa (1997) (Table 1).

The total DNA was extracted from the soil samples using the PowerSoil ${ }^{\mathrm{TM}}$ kit (MO BIO Laboratories Inc., Carlsbad, CA, USA) according to the manufacturer's instructions. The DNA concentration and quality were quantified using the NanoVue spectrophotometer (GE Healthcare, Harriet, USA).

\section{Real-time quantification of 16S rRNA gene targets} Abundance of Bacteria and Archaea domains were measured by real-time quantification of $16 \mathrm{~S}$ rRNA gene targets. To avoid the effect of preferential amplification of certain microbial groups (Bergmann et al., 2011) we used two sets of primers to cover the regions V3 and V6 of the 16S rRNA gene. This may lead to different depths of microbial capture from environmental samples, attributed to different amplification efficiency rates and primer specificity (Wang and Qian, 2009). For amplification of the Bacteria domain we used the primers 341F (5'-CCTACGGGAGGCAGCAG-3') and 518R (5'-CCAGCAGCCGCGGTAAT-3') (Bartram et al., 2011) and 917F (5'-GAATTGACGGGGRCCCGC-3') and 1061R (5'-CACGRCACGAGCTGACGAC-3') (Degnan and Ochman, 2012). For amplification of the Archaea domain we used the primers 344F (Casamayor et al., 2002) and 519R (Ovreas et al., 1997) and 958F and 1048R (Galand et al., 2009). The qPCR's were performed in a reaction volume of $20 \mu \mathrm{L}$ containing 2 X QuantiTect SYBR Green PCR Master Mix (Qiagen, Valencia, CA, USA), $10 \mu \mathrm{mol} \mathrm{L} \mathrm{L}^{-1}$ of each primer and $15 \mathrm{ng}$ of DNA template. DNA amplification and detection were performed in duplicated reactions using the Rotor-GeneQ ${ }^{\circledR}$ detection system (Qiagen, Valencia, CA, USA) and by the Rotor-Gene Q Series software, version 2.0.2. For each set of primers, a two-step PCR with melting were performed under the following reaction conditions: $95{ }^{\circ} \mathrm{C}$ for $15 \mathrm{~min}$ followed by 30 cycles of $95^{\circ} \mathrm{C}$ for $15 \mathrm{~s}$ and $55^{\circ} \mathrm{C}$ for $30 \mathrm{~s}$. Melting curve analysis of the PCR products was conducted following each assay to confirm the specificity of the primers and to check if the fluorescence signal had originated from specific PCR products and not from primer-dimers or other artifacts. To estimate Bacterial and Archaeal 16S gene abundances, standard curves were generated using 10-fold serial dilutions using the method described by Fierer et al. (2005). Gene copy numbers were determined using a regression equation for each assay and relating the cycle threshold (CT) value to the known numbers of copies in the standards. The $16 \mathrm{~S}$ gene copy numbers obtained for the forest and pasture were compared by $\mathrm{F}$ test at a $1 \%$ probability.

\section{RISA analysis}

The microbial community structure was determined by the ribosomal intergenic spacer analysis (RISA), which explores the intergenic spacer between the $16 \mathrm{~S}$ and $23 \mathrm{~S}$ rRNA subunits for constructing microbial community fingerprints based on the length heterogeneity of the intergenic transcribed spacer region of bacterial and archaeal rRNA operons. The intergenic spacer of archaea was amplified using the primers 64RA (reverse - 5'-GCC ATC CTT GCA NRG GCT T-3 ') (Summit and Baross, 2001) and 21FA (forward - 5'-TTC CGG TTG GCC TAC CYG GA-3 ') (DeLong, 1992). The primers LDBact-132nd-A-18 (reverse - 5'-CCG GGT TTC CCC ATT CGG-3 ') and SD-Bact-1522-b-S-20 (forward - 5'-TGC GGC TGG CCC TCC ATC TT) were used to amplify the 
intergenic spacer from the Bacteria domain (Ranjard et al., 2001). The PCR conditions were: $94^{\circ} \mathrm{C}$ for $3 \mathrm{~min}, 30$ cycles of $94{ }^{\circ} \mathrm{C}$ for $45 \mathrm{~s}, 55^{\circ} \mathrm{C}$ for $1 \mathrm{~min}$ and $72^{\circ} \mathrm{C}$ for 2 min and finally 1 cycle of $72^{\circ} \mathrm{C}$ for $7 \mathrm{~min}$. PCR reactions were performed with PCR GoTaq core system (Promega, Madison, WI, USA) in $50 \mu \mathrm{L}$ reaction mixtures, including $5 \mu \mathrm{L} \mathrm{10X} \mathrm{PCR} \mathrm{Buffer,} 200 \mathrm{mmol} \mathrm{L}^{-1}$ of dNTPs mix, $100 \mathrm{mmol} \mathrm{L}^{-1}$ of each primer, $2.5 \mathrm{U}$ Taq polymerase and approximately $100 \mathrm{ng}$ of DNA template. An aliquot of $5 \mu \mathrm{L}$ of the amplification product stained with a mixture of 10X xylene cyanol / Bromophenol blue DNA loading buffer and GelRed 10.000x was analyzed on $2 \%$ agarose gel in 1X TBE buffer (Sambrook and Russell, 2001), using a standard molecular Ladder of $100 \mathrm{bp}$. Gels were run at $80 \mathrm{~V}$ for $6 \mathrm{~h}$ and subsequently scanned using a photo documentation device.

RISA profiles were used to generate a binary matrix (presence/absence) with Gel-Pro Analyzer program (Media Cybernetics, USA) with a $5 \%$ threshold. The bacterial and archaeal data were analyzed using multivariate techniques. To compare the genetic structure between samples, a matrix of similarity (Jaccard similarity coefficient) was calculated from the binary matrix with PRIMER 6 (Clarke and Gorley, 2006). Changes in relative similarities of each site were measured using ranks of similarity represented by non-metric multidimensional scaling (NMDS) where ordination distance ranking was shown using Kruscal's stress value, which indicates the degree of inconsistency between the similarity matrix and the final configuration of the plots. This value should be less than 0.2 to give a good and accurate representation of the similarities between the samples where stress values below 0.05 indicate that the configuration of the samples within ordination had a low probability of error (Clarke, 1993). Associated with NMDS, one-way analysis of similarity (ANOSIM) tests were used to assess significant differences in microbial composition of land uses, which use a similarity matrix (the same used for NMDS) to calculate an $\mathrm{R}$ test statistic. $\mathrm{R}$ values represented a difference of average rank similarities between and within groups, which can vary between 0 and 1 . R-values near 0 indicate a true null hypothesis of no difference between groups, whereas those greater than 0 indicate discrimination between groups (reaching a maximum of 1 , when similarities within groups are greater than any similarities between groups - Clarke and Gorley, 2006). $R$ values less than 0.5 indicate that the microbial compo- sition does not differ statistically between samples and $\mathrm{R}$ values greater or equal to 0.5 indicate that the microbial composition differ significantly between samples (Wertz et al., 2007). Additionally, a hierarchical cluster analysis was used to produce dendrograms of similarity for each microbial domain computed with 1.000 bootstrap replications.

\section{Results}

Soil microbial community abundance and structure The number of $16 \mathrm{~S}$ ribosomal DNA copies did not present significant differences between forest and pasture samples (Table 2). Irrespective of the $16 \mathrm{~S}$ region evaluated (V3 or V6) neither domain, Bacteria or Archaea, presented significant variation in the number of the $16 \mathrm{~S}$ gene copies, meaning that the land use did not cause alterations in the total numbers of each domain. Although the total number of gene copies did not differ between land uses, the similarity or difference in abundance of these large groups does not mean that the species present in land uses were the same. To further explore microbial structure differences between land uses we applied a fingerprinting technique.

To better judge (di) similarities between microbial communities from different land uses, RISA profiles were used to calculate nonmetric multidimensional scaling (NMDS) plots associated with analysis of similarities (ANOSIM) of bacterial and archaeal communities. The NMDS was used to visualize the similarity between groups of soil microbes from forest and pasture. According to the tests, changes in land use affected both bacterial and archaeal communities at the site evaluated (Figure $1 \mathrm{~A}$ and B). The proximity between samples in the plot corresponds to high community similarity, and the quality of the ordination is indicated by a low-stress value. The global $\mathrm{R}$, which is the average pairwise $\mathrm{R}$ for each group and indicates the general (di) similarity of the microbial community analyzed, was $0.953(p<0.05)$ for the bacterial community, revealing significant differences between forest and grassland, and $0.318(p<0.05)$ for the archaeal community, indicating that the archaeal communities in these areas are different but present overlapping groups.

In addition to the NMDS and ANOSIM analysis, we used hierarchical cluster analysis to compare microbial community profiles with each other. We found that bacterial community composition was strongly affected

Table 2 - Number of $16 \mathrm{~S}$ ribosomal DNA copies of bacteria and archaea measured using quantitative Polymerase Chain Reaction (qPCR) in forest and pasture soil samples.

\begin{tabular}{|c|c|c|c|c|c|c|}
\hline \multirow[t]{2}{*}{ Domain } & \multirow[t]{2}{*}{ Primers } & \multirow[t]{2}{*}{$16 S$ region } & \multicolumn{2}{|c|}{ 16S gene copy number $\mathrm{g}^{-1}$ of soila } & \multirow{2}{*}{$\frac{\text { qPCR efficiency }}{\%}$} & \multirow[t]{2}{*}{$\mathrm{R}^{2}$} \\
\hline & & & Forest & Pasture & & \\
\hline \multirow{2}{*}{ Bacteria } & Bac-341F / Bac-518R & V3 & $6.5 \times 10^{6}$ & $6.8 \times 10^{6}$ & 90 & 0.98 \\
\hline & Bac-917F / Bac-1061R & V6 & $4.2 \times 10^{6}$ & $4.2 \times 10^{6}$ & 95 & 0.99 \\
\hline \multirow{2}{*}{ Archaea } & Arc-344F / Arc-519R & V3 & $8.7 \times 10^{3}$ & $8.0 \times 10^{3}$ & 94 & 0.98 \\
\hline & Arc-958F / Arc-1048R & V6 & $1.2 \times 10^{4}$ & $1.0 \times 10^{4}$ & 93 & 0.98 \\
\hline
\end{tabular}

aThe mean values found between forest and pasture were not significantly different according to the $\mathrm{F}$ Test $(p<0.01)$. 


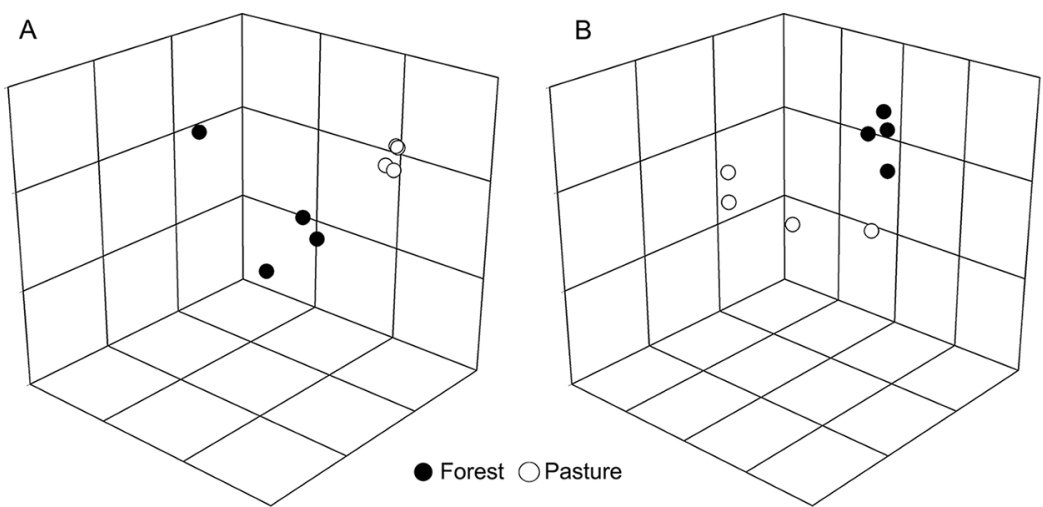

Figure 1 - 3D Nonmetric multidimensional scaling (NMDS) plots of bacterial (A) and archaeal (B) communities structure determined by Ribossomal Intergenic Spacer Analysis (RISA) profiles. The stress values for all plots were 0.01, which indicate that these data were well-represented by the three-dimensional representation.

by land use change. The dendrogram defined two separated major clusters demonstrating a clear difference in RISA profile between forest and pasture supported by high bootstrap values (Figure 2A). The similarity between both main clusters was around $15 \%$. The cluster formed by only forest samples was less similar $130 \%$ similarity) compared to the group formed by pasture samples (70\% similarity). The cluster analysis of archaeal community did not clearly separate forest and pasture into separated groups, but presented a dendrogram with three groups (Figure 3A). The first cluster was composed of three samples of pasture (1,2 and 4) with about $35 \%$ of similarity and the second cluster was composed of three samples from the forest and one sample from the pasture, with about $38 \%$ similarity. These two groups were clustered together with low bootstrap support values. A third cluster consisted of only one forest sample, with about $18 \%$ similarity to two other clusters, which is supported by a high bootstrap value.

The Venn diagram (Figure 2B and 3B) demonstrates the distribution of soil bacterial and archaeal OTUs between forest and pasture. The pasture and forest systems showed high dissimilarity in bacterial community data as shown by ANOSIM and clear separation in cluster analysis, suggesting differences in the structure and membership of the communities (Figure 2B). The Venn diagram further confirmed these observations, indicating that only $22 \%$ of bacterial OTUs were shared between the two land uses. Unlike the bacterial community, the archaeal community from forest and pasture showed low values of dissimilarity according to the ANOSIM analysis and high similarity according to the cluster analysis. These results explain the high overlap found in the Venn diagram, which revealed that $50 \%$ of archaeal OTUs were shared between forest and pasture (Figure 3B). Furthermore, the diagram showed approximately $61 \%$ of OTUs found only in the forest and 17 $\%$ of OTUs of bacteria were found only in the pasture. While for archaeas, $31 \%$ and $19 \%$ of OTUs were found only in the forest and grassland, respectively.

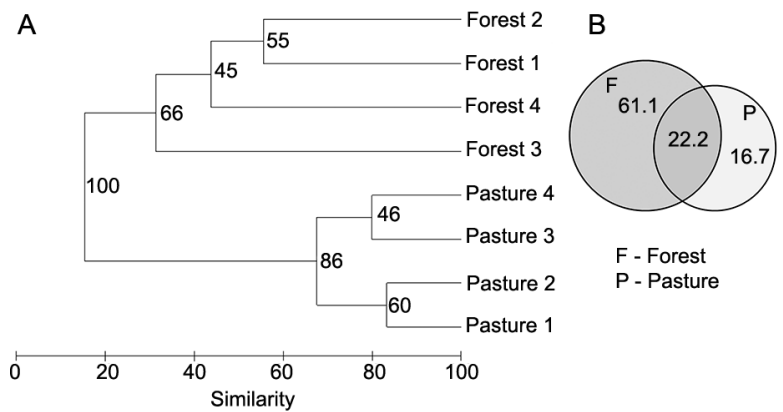

Figure 2 - A) Hierarchical cluster analysis based on Ribossomal Intergenic Spacer Analysis (RISA) profile of soil bacterial community. Numbers on the branches are percentages of 1,000 bootstrap samples supporting the branch. B) Venn diagram of bacterial Operational Taxonomic Unities (OTUs) clustered with a $5 \%$ distance threshold, showing the number of OTUs shared by the two land uses. The size of the spheres is consistent with the amount of OTUs present. Values are expressed in percentages.

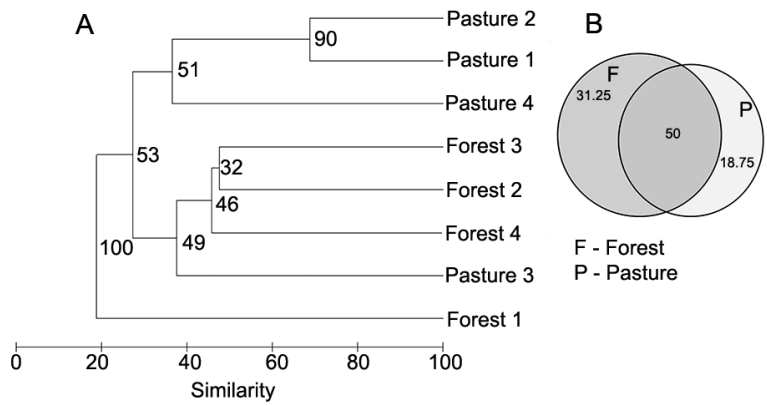

Figure 3 - A) Hierarchical cluster analysis based on Ribossomal Intergenic Spacer Analysis (RISA) profile of soil archaeal community. Numbers on the branches are percentages of 1,000 bootstrap samples supporting the branch. B) Venn diagram of archaeal Operational Taxonomic Unities (OTUs) clustered with a $5 \%$ distance threshold, showing the number of OTUs shared by the two land uses. The size of the spheres is consistent with the amount of OTUs present. Values are expressed in percentages. 


\section{Discussion}

In this study, we tested the hypothesis that land use change causes alterations in soil archaeal and bacterial communities and these domains respond in different ways, one being more affected than the other. To test this hypothesis, we assessed and compared the abundance and structure of soil bacterial and archaeal communities present in the surface layer from bulk soil samples from two land uses (pasture and native forest) within the same soil type by using quantitative PCR and RISA profiles. The area chosen for sampling was ideal for testing the effect caused by removing plant cover since it presented low human activity, no inputs of fertilizers and very low animal influence. It should be noted, however, that these results represent a single point in time (June, 2010) and variations in plant growth cycles and time cannot be considered in our study. Though seasonal dynamics might affect the trends observed across the microbial taxa, previous studies have shown that long-term patterns within these microbial communities are expected to remain generally intact (Williams et al., 2013). Two regions of the 16S rRNA gene (V3 and V6) were amplified by quantitative PCR and the intergenic region located between the small (16S) and large (23S) subunit of the rRNA genes was amplified from microbial DNA extracted directly from four composite samples from each land use. The qPCR approach is somewhat unique among methods of community analysis in that it allows for a relatively rapid assessment of the abundance of specific phylogenetic groups of microorganisms in soil (Fierer et al., 2005). Such PCR-based profiling tools have been applied to the assessment of the influence of different agricultural management approaches on the microbial community in soil (Grandy et al., 2009; Kong et al., 2010). The RISA method is considered a highly reproducible fingerprint technique that allows for easy comparison between samples (Elsas and Boersma, 2011). The intergenic spacer is extremely variable in both sequence and length (ranging from $50 \mathrm{bp}$ to more than $1.5 \mathrm{~kb}$ ) among different taxa allowing for rapid assessment of the genetic structure of complex communities in soil environments (Borneman and Triplett, 1997).

Even using two different regions of the $16 \mathrm{~S}$ rRNA genes to estimate bacterial and archaeal abundance, we verified no effect $(p>0.01)$ of land use on soil bacterial and archaeal abundance. However, it is also important to recognize that similarity or difference in abundance does not mean that the species present in land uses were the same. The same abundance might indicate the soil archaeal and bacterial communities under the influence of environmental shifts which will gradually be replaced by another community composed of different species that survive better under the new conditions. Due to problems inherent in the PCR that seem to exclude some phyla during amplification, different regions of the $16 \mathrm{~S}$ rRNA gene were amplified for each microbial group. Bergmann et al. (2011) found that most primers used by the scientific community underestimate the abundance of the phylum Verrucomicrobia probably because many of the commonly used primers seem to exclude this phylum during PCR amplification. Because this gene presents hypervariable regions that exhibit different degrees of sequence diversity, a single hypervariable region would not be able to distinguish between all microorganisms (Chakravorty et al., 2007). Therefore, the use of different sets of primers result in variations in different phyla in abundance.

The DNA extraction methods can affect the microbial community and biases in PCR may also occur. This is a very important point that has to be resolved especially when the goal is to obtain accurate estimates of microbial richness, or alpha diversity, and a real view of the structure of microbial communities (Gonzalez et al., 2012). However, this problem has been considered as being of less concern for comparisons of beta diversity (Huber et al., 2009; Engelbrektson et al., 2010). From approaches based only on the fingerprint of microbial communities it is not possible to identify which taxa are present in the soil. However, it is known that due to differences in the size of fragments obtained from the amplification of the intergenic space, the fragments can be derived from distinct taxonomic groups.

Although the overall abundance of bacteria and archaea did not differ $(p>0.01)$ between pasture and adjacent native forest, the RISA data revealed differences in bacterial and archaeal community structure. Since the selected sites were characterized by the same soil type and same weather conditions, we consider that the land use change, the new plant community and the edaphic properties might be the main factors responsible for alterations in the bacterial and the archaeal groups. The removal of forest vegetation and further conversion to pasture with the consequent reduction of plant diversity and decrease of $\mathrm{Ca}+\mathrm{Mg}, \mathrm{P}, \mathrm{Al}$ and humin content should be taken into account to explain the alterations in the bacterial and archaeal structure at this site. Plant cover affects microbial communities because of the quality and amount of leaf and root litter together with root exudates (Wallenius et al., 2011). In addition to the direct effects of litter on microbial communities, land use change can indirectly affect soil microbial composition through alterations in soil properties like soil density, infiltration and evaporation of water, moisture and bioavailability of nutrients (Young and Crawford, 2004; Singh et al., 2009; Wakelin et al., 2008; Wallenius et al., 2011). However, the way in which these factors would influence the structure of a given community remains unclear.

All of the factors mentioned above have profound effects on soil microorganisms, and it is therefore expected that soil with a divergent management system contains dissimilar microbial communities. Although the changes in land use caused alterations in the structure of soil bacterial and archaeal communities, these microbes showed different responses to the removal of forest cov- 
er. The Archaea domain was apparently less affected by the disturbance than the Bacteria. According to Allison and Martiny (2008), the microbial composition or structure might be resistant to a disturbance applied to an ecosystem. This can be explained by several factors. A number of microbial groups show a high degree of metabolic flexibility and physiological tolerance to changes in environmental conditions (Meyer et al., 2004). The resistance to disturbance might also be explained by high abundance, widespread dispersal, and the potential for rapid growth rates (Fenchel and Finlay, 2004). Also, the soils offer a variety of heterogeneous habitat niches for microorganisms that can be highly variable, both on a microscopic and a macroscopic scale. One example is the contradictory correlations between soil properties/ activity and the abundance of Amonia Oxidizing Bacteria $(\mathrm{AOB})$ and Amonia Oxidizing Archaea (AOA). The proposed explanation for the division is based on nutrient status, with low nutrient habitats being the preferred environment for the AOA (Erguder et al., 2009).

The amount of OTUs shared between the native forest and the pasture might suggest the prevalence of a resilient microbial community that did not suffer any alteration related to land use or edaphic properties. This can be explained by a different hypothesis: i) the soil is the main driver of bacterial and archaeal communities. This view is supported by a number of works reporting that soil type strongly influences bacterial and archaeal communities even under distinct management systems or irrespective of the absence or presence of vegetation (Hoshino et al., 2011; Kuramae et al., 2012; Lupatini et al., 2013); ii) the pasture was surrounded by a large forest area, which should serve as an inoculum for microbial re-colonization (Jesus et al., 2009); iii) a number of microbial groups show a high degree of metabolic and physiological flexibility to variations in the environmental conditions (Allison and Martiny, 2008). The existence of a well-adapted soil microbial community in this case is independent of vegetation cover, modifications on edaphic properties (Marshall et al., 2011), or soil properties (Nacke et al., 2011) and can exhibit a great level of similarity despite a number of modifications in soil chemical properties (Wallenius et al., 2011); iv) the apparent resilience or resistance of microbial community to disturbance might be explained by cell dormancy (Jones and Lennon, 2010). Lennon and Jones (2011) suggest that dormancy should explain a variety of ecology process detected in several studies related to resistance and resilience.

In addition to detecting alterations in microbial community structure and the presence of a soil microbial core, we were able to detect shifts in the absence/ presence of few specific bacterial and archaeal groups related to each land use. It is possible that only specific bacterial and archaeal groups respond to alterations in the aboveground vegetation or edaphic properties, and these groups would have a low abundance in soils (Felske and Akkermans, 1998). According to Kuramae et al.
(2011), the higher nutrient conditions present in the arable field samples are apparently selected for specific members of the Bacterioidetes, Planctomycetes, Alpha-, Beta- and Gammaproteobacteria, and it is reasonable to suppose that many of these populations represent soilborne copiotrophs. Extending these arguments to later succession stages, it is expected that the lower nutrient status of these soils select a higher proportion of oligotrophic microorganisms (Kuramae et al., 2011). This observation may be indicative that environmental changes might gradually replace soil microbial communities by another community composed of different species that survive better under the new conditions (Allison and Martiny, 2008).

\section{Conclusions}

The response of the soil microbial community to land use changes is not straightforward and the dynamics of soil microbiota is partly driven by several intrinsic factors. Nevertheless, on the basis of these findings, we conclude that differences observed in bacterial and archaeal communities were occasioned through the effects of soil attributes or by the modification of dominant vegetation. Although the removal of vegetation has not caused alterations in microbial abundance, the structure of communities of bacteria and archaea were modified, and although these microbial groups have responded in different ways to the impact caused, it was found that bacteria, compared to archaea, presented fewer organisms shared between both environments. However, the number of organisms shared between forest and pasture for bacteria and archaea suggested the presence of a microbial community that did not suffer modification related to modification of land use or that the disturbance caused by land use change was not enough to alter the soil microbial community.

\section{Acknowledgements}

This work was supported by the Brazilian National Council for Scientific and Technological Development (CNPq - grant number 476121/2010-8). L.F.W. Roesch received research fellowships from the $\mathrm{CNPq}$ and A.K.A. Suleiman received research fellowships from the Coordination for the Improvement of Higher Level Personnel (CAPES).

\section{References}

Allison, S.D.; Martiny, J.B.H. 2008. Resistance, resilience, and redundancy in microbial communities. Proceedings of the National Academy of Sciences 105: 11512-11519.

Baker, K.S.; Langenheder, S.; Nicol, G.W.; Ricketts, D.; Killham, K.; Campbell, C.D.; Prosser, J.I. 2009. Environmental and spatial characterisation of bacterial community composition in soil to inform sampling strategies. Soil Biology \& Biochemistry 41: 2292-2298. 
Bartram, A.K.; Lynch, M.D.; Stearns, J.C.; Moreno-Hagelsieb, G.; Neufeld, J.D. 2011. Generation of multimillion-sequences $16 \mathrm{~S}$ rRNA gene libraries from complex microbial communities by assembling paired-end Illumina reads. Applied and Environmental Microbiology 77: 3846-3852.

Bergmann, G.; Bates, S.T.; Eilers, K.G.; Lauber, C.L.; Caporaso, J.G.; Walters, W.A.; Knight, R.; Fierer, N. 2011. The underrecognized dominance of Verrucomicrobia in soil bacterial communities. Soil Biology \& Biochemistry 43: 1450-1455.

Borneman, J.; Triplett, E.W. 1997. Molecular microbial diversity in soils from Eastern Amazonia: evidence for unusual microorganisms and population shifts associated with deforestation. Applied and Environmental Microbiology 63: 2647-2653.

Casamayor, E.O.; Massana, R.; Benlloch, S.; Ovreas, L.; Diez, B.; Goddard, V.J.; Gasol, J.M.; Joint, I.; Rodríguez-Valera, F; Pedrós-Alió, C. 2002. Changes in archaeal, bacterial and eukaryal assemblages along a salinity gradient by comparison of genetic fingerprinting methods in a multipond solar saltern. Environmental Microbiology 4: 338-348.

Chakravorty, C.; Helb, D.; Burday, M.; Connell, N.; Alland, D. 2007. A detailed analysis of $16 \mathrm{~S}$ ribosomal RNA gene segments for the diagnosis of pathogenic bacteria. Journal of Microbiological Methods 69: 330-339.

Clarke, K.R. 1993. Non-parametric multivariate analyses of changes in community structure. Australian Journal of Ecology 18: $117-143$.

Clarke, K.R.; Gorley, R.N. 2006. PRIMER v6: User Manual/ Tutorial. PRIMER-E, Plymouth, UK.

Degnan, P.H.; Ochman, H. 2012. Illumina-based analysis of microbial community diversity. The ISME Journal 6: 183-94.

DeLong, E.F. 1992. Archaea in coastal marine environments. Proceedings of the National Academy of Sciences 89: 56855689.

Elsas, J.D.; Boersma, F.G.H. 2011. A review of molecular methods to study the microbiota of soil and the mycosphere. European Journal of Soil Biology 47: 77-87.

Empresa Brasileira de Pesquisa Agropecuária [Embrapa]. 1997. Manual of Methods for Soil Analysis = Manual de Métodos de Análises de Solos. 2ed. Centro Nacional de Pesquisa de Solos, Rio de Janeiro, RJ, Brazil (in Portuguese).

Engelbrektson, A.; Kunin, V.; Wrighton, K.C.; Zvenigorodsky, N.; Chen, F.; Ochman, H.; Hugenholtz, P. 2010. Experimental factors affecting PCR-based estimates of microbial species richness and evenness. The ISME Journal 4: 642-647.

Erguder, T.H.; Boon, N.; Wittebolle, L.; Marzorati, M.; Verstraete, W. 2009. Environmental factors shaping the ecological niches of ammonia-oxidizing archaea. FEMS Microbiology Reviews 33: 855-869.

Fenchel, T.; Finlay, B.J. 2004. The ubiquity of small species: patterns of local and global diversity. BioScience 54: 777-784.

Felske, A.; Akkermans, A.D.L. 1998. Spatial homogeneity of abundant bacterial 16S rRNA molecules in grassland soils. Microbial Ecology 36: 31-36.

Fierer, N.; Jackson, J.A.; Vilgalys, R.; Jackson, R.B. 2005. Assessment of soil microbial community structure by use of taxon-specific quantitative PCR assays. Applied and Environmental Microbiology 71: 4117-4120.
Fliessbach, A.; Oberholzer, H.R.; Gunst, L.; Mäder, P. 2007. Soil organic matter and biological soil quality indicators after 21 years of organic and conventional farming. Agriculture, Ecosystems \& Environment 118: 273-284.

Galand, P.E.; Casamayor, E.O.; Kirchman, D.L.; Potvin, M.; Lovejoy, C. 2009. Unique archaeal assemblages in the Arctic Ocean unveiled by massively parallel tag sequencing. The ISME Journal 3: 860-869.

García-Orenes, F.; Cerdà, A.; Mataix-Solera, J.; Guerrero, C.; Bodí, M.B.; Arcenegui, V.; Zornoza, R.; Sempere, J.G. 2009. Effects of agricultural management on surface soil properties and soil-water losses in eastern Spain. Soil and Tillage Research 106: 117-123.

Gonzalez, J.M.; Portillo, M.C.; Belda-Ferre, P.; Mira, A. 2012. Amplification by PCR artificially reduces the proportion of the rare biosphere in microbial communities. Plos One 7: e29973.

Govaerts, B.; Mezzalama, M.; Unno, Y.; Sayre, K.D.; Luna-Guido, M.; Vanherck, K.; Dendooven, L.; Deckers, J. 2007. Influence of tillage, residue management, and crop rotation on soil microbial biomass and catabolic diversity. Applied Soil Ecology 37: 18-30.

Grandy, A.S.; Strickland, M.S.; Lauber, C.L.; Bradford, M.A.; Fierer, N. 2009. The influence of microbial communities, management, and soil texture on soil organic matter chemistry. Geoderma 150: 278-286.

Hoshino, Y.T.; Morimot, S.; Hayatsu, M.; Nagaoka, K.; Suzuki, C.; Karasawa, T.; Takenaka, M.; Akiyama, H. 2011. Effect of soil type and fertilizer management on archaeal community in upland field soils. Microbes and Environments 26: 307-316.

Huber, J.A.; Morrison, H.G.; Huse, S.M.; Neal, P.R.; Sogin, M.L.; Mark Welk, D.B. 2009. Effect of PCR amplicon size on assessments of clone library microbial diversity and community structure. Environmental Microbiology 11: 1292-1302.

Jesus, E.C.; Marsh, T.L.; Tiedje, J.M.; Moreira, F.M.S. 2009. Changes in land use alter the structure of bacterial communities in western Amazon soils. The ISME Journal 3: 1004-1011.

Jones, S.E.; Lennon, J.T. 2010. Dormancy contributes to the maintenance of microbial diversity. Proceedings of the National Academy of Sciences 107: 5881-5886.

Kong, A.Y.Y.; Hristova, K.; Scow, K.M.; Six, J. 2010. Impacts of different $\mathrm{N}$ management regimes on nitrifier and denitrifier communities and $\mathrm{N}$ cycling in soil microenvironments. Soil Biology \& Biochemistry 42: 1523-1533.

Kuramae, E.E.; Yergeau, E.; Wong, L.C.; Pijl, A.S.; van Veen, J.A.; Kowalchuk, G.A. 2012. Soil characteristics more strongly influence soil bacterial communities than land-use type. FEMS Microbiology Ecology 1: 12-24.

Kuramae, E.E.; Yergeau, E.; Wong, L.; Pijl, A.; van Veen, J.A.; Kowalchuk, G.A. 2011. Soil and plant factors driving the community of soil-borne microorganisms across chronosequences of secondary succession of chalk grasslands with a neutral pH. FEMS Microbiology Ecology 77: 229-459.

Lennon, J.T.; Jones, S.E. 2011. Microbial seed banks: ecological and evolutionary implications of dormancy. Nature Reviews Microbiology 9: 119-130.

Lupatini, M.; Jacques, R.J.S.; Antoniolli, Z.I.; Suleiman, A.S.; Fulthorrpe, R.R.; Roesch, L.F.W. 2013a. Land-use change and soil type are drivers of fungal and archaeal communities in the Pampa biome. World Journal of Microbiology and Biotechnology 29: 223-233. 
Lupatini, M.; Suleiman, A.K.A.; Jacques, R.J.S.; Antoniolli, Z.I.; Kuramae, E.E.; Camargo, F.A.O.C.; Roesch, L.F.W. 2013b. Soil-borne bacterial structure and diversity does not reflect community activity in Pampa biome. Plos One 8: e76465.

Maitima, J.M.; Mugatha, S.M.; Reid, R.S.; Gachimbi, L.N.; Majule, A.; Lyaruu, H.; Pomery, D.; Mathai, S.; Mugisha, S. 2009. The linkages between land use change, land degradation and biodiversity across east Africa. African Journal of Environmental Science and Technology 10: 310-325.

Marshall, C.B.; McLaren, J.R.; Turkington, R. 2011. Soil microbial communities resistant to changes in plant functional group composition. Soil Biology \& Biochemistry 43: 78-85.

Meyer, A.F.; Lipson, D.A.; Martin, A.P.; Schadt, C.W.; Schmidt, S.K. 2004. Molecular and metabolic characterization of coldtolerant alpine soil Pseudomonas sensu stricto. Applied and Environmental Microbiology 70: 483-489.

Nacke, H.; Thürmer, A.; Wollherr, A.; Will, C.; Hodac, L.; Herold, N.; Schöning, I.; Schrumpf, M.; Daniel, R. 2011. Pyrosequencing-based assessment of bacterial community structure along different management types in German forest and grassland soils. Plos One 6: e17000.

Nicol, G.W.; Glover, A.; Prosser, J.I. 2003. The impact of grassland management on archaeal community structure in upland pasture rhizosphere. Environmental Microbiology 5: 152-162.

Osborne, C.A.; Zwart, A.B.; Broadhurst, L.M.; Young, A.G.; Richardson, A.E. 2011. The influence of sampling strategies and spatial variation on the detected soil bacterial communities under three different land-use types. FEMS Microbiology Ecology 78: 70-79.

Overbeck, G.E.; Müller, S.C.; Pillar, V.D.; Pfadenhauer, J. 2006. Floristic composition, environmental variation and species distribution patterns in burned grassland in southern Brazil. Brazilian Journal of Biology 66: 1073-1090.

Ovreas, L.; Forney, L.; Daae, F.L.; Torsvik, V. 1997. Distribution of bacterioplankton in meromictic Lake Saelenvannet, as determined by denaturing gradient gel electrophoresis of PCRamplified gene fragments coding for 16S rRNA. Applied and Environmental Microbiology 63: 3367-3373.

Ranjard, L.; Poly, F.; Lata, J.C.; Mougel, C.; Thioulouse, J.; Nazret, S. 2001. Characterization of bacterial and fungal soil communities by automated ribosomal intergenic spacer analysis fingerprints: biological and methodological variability. Applied and Environmental Microbiology 67: 4479-4487.

Roesch, L.F.W.; Vieira, F.C.; Pereira, V.A.; Schünemann, A.L.; Teixeira, I.F.; Senna, A.J.T.; Stefenon, V.M. 2009. The Brazilian pampa: a fragile biome. Diversity 2: 182-198.

Romaniuk, R.; Giuffre, L.; Costantini, A.; Bartoloni, N.; Nannipieri, P. 2011. A comparison of indexing methods to evaluate quality of soils: the role of soil microbiological properties. Soil Research 49: 733-741.
Schjønning, P.; Munkholm, L.J.; Elmoholt, S.; Olesen, J.R.E. 2007. Organic matter and soil tilth in arable farming: management makes a difference within 5-6 years. Agriculture, Ecosystems \& Environment 122: 157-172.

Singh, B.K.; Dawson, L.A.; MacDonald, C.A.; Buckland, S.M. 2009. Impact of biotic and abiotic interaction on soil microbial communities and functions: a field study. Applied Soil Ecology 41: 239-248.

Suleiman, A.K.A.; Lupatini, M.; Boldo, J.T.; Pereira, M.G.; Roesch, L.F.W. 2013. Shifts in soil bacterial community after 8 years of land-use change. Systematic and Applied Microbiology 36: $137-144$

Summit, M.; Baross, J.A. 2001. A novel microbial habitat in the mid-ocean ridge subseafloor. Proceedings of the National Academy of Sciences 98: 2158-2163.

Tilman, D.; Fargione, J.; Wolff, B.; D'Antonio, C.; Dobson, A.; Howarth, R.; Schindler, D.; Schlesinger, W.H.; Simberloff, D.; Swackhamer, D. 2001. Forecasting agriculturally driven global environmental change. Science 292: 281-284.

Wallenius, K.; Rita, H.; Mikkonen, A.; Lappi, K.; Lindström, K.; Hartikainen, H.; Raateland, A.; Niemi, R.M. 2011. Effects of land use on the level, variation and spatial structure of soil enzyme activities and bacterial communities. Soil Biology \& Biochemistry 43: 1464-1473.

Wakelin, S.A.; MacDonald, L.M.; Rogers, S.L.; Gregg, A.L.; Bolger, T.P.; Baldock, J.A. 2008. Habitat selective factors influencing the structural composition and functional capacity of microbial communities in agricultural soils. Soil Biology \& Biochemistry 40: 803-813.

Wang, Y.; Qian, P.Y. 2009. Conservative fragments in bacterial $16 \mathrm{~S}$ rRNA genes and primer design for $16 \mathrm{~S}$ ribosomal DNA amplicons in metagenomic studies. Plos One 4: e7401.

Wertz, S.; Czarnes, S.; Bartoli, F.; Renault, P.; Commeaux, C.; Guillaumaud, N.; Clays-Josserand, A. 2007. Early-stage bacterial colonization between a sterilized remoulded soil clod and natural soil aggregates of the same soil. Soil Biology \& Biochemistry 39: 3127-3137.

Williams, M.A.; Jangid, K.; Shanmugam, S.G.; Whitman, W.B. 2013. Bacterial communities in soil mimic patterns of vegetative succession and ecosystem climax but are resilient to change between seasons. Soil Biology \& Biochemistry 57: 749-757.

Young, I.M.; Crawford, J.W. 2004. Interactions and selforganization in the soil-microbe complex. Science 304: 16341637. 